\title{
POTRET PEMBELAJARAN DARING MATAKULIAH KAJIAN KEBAHASAAN DI PGSD FIP UNIMED
}

\author{
Faisal \\ Surel: faisalpendas@gmail.com
}

\begin{abstract}
The purpose of this study is to describe the implementation of online learning for the even semester 2020/2021 Language Studies course in the PGSD FIP UNIMED study program. This research is a qualitative descriptive study. The population used in this study were all second semester students who took the Language Studies course at the PGSD FIP UNIMED Study Program. Samples were taken involving 187 respondents. The instrument used in the study was an online questionnaire with a google form. The data analysis technique was carried out by qualitative analysis with 4 stages of activities, including: data collection, data reduction, data presentation, and drawing conclusions. The results showed: (1) the average score of the teaching and learning process is 4.11 (Good), (2) the average score of capability/competence of lecturers is 4.28 (Good), (3) the average score of supporting facilities and infrastructure is 3,93 (Good), and (4) the most dominant challenge is the need to improve IT skills and effectiveness in time management.
\end{abstract}

Keywords: online learning, language studies, PGSD.

\begin{abstract}
ABSTRAK
Tujuan dari penelitian ini mendeskripsikan implementasi pembelajaran daring matakuliah Kajian Kebahasaan semester genap 2020/2021 di prodi PGSD FIP UNIMED. Penelitian ini merupakan penelitian deskriptif kualitatif. Populasi yang digunakan dalam penelitian ini adalah seluruh mahasiswa semester II yang mengambil matakuliah Kajian Kebahasaan di Prodi PGSD FIP UNIMED. Sampel yang diambil dengan melibatkan 187 responden. Instrumen yang digunakan dalam penelitian adalah kuesioner secara daring dengan google form. Teknik analisis data dilakukan dengan analisis kualitatif dengan 4 tahapan kegiatan antara lain: pengumpulan data, reduksi data, penyajian data, dan penarikan simpulan. Hasil penelitian menunjukkan : (1) skor ratarata proses belajar mengajar sebesar 4,11 (Baik), (2) skor rata-rata kapabilitas/kompetensi dosen sebesar 4,28 (Baik), (3) skor rata-rata sarana dan prasarana pendukung sebesar 3,93 (Baik), dan (4) tantangan yang paling dominan adalah mengharuskan peningkatan keterampilan IT dan keefektifan dalam manajemen waktu.
\end{abstract}

Kata Kunci: Pembelajaran Daring, Kajian Kebahasaan, PGSD

\section{PENDAHULUAN}

$\begin{array}{llr}\text { Salah } & \text { satu } & \text { kebijakan } \\ \text { Universitas Negeri } & \text { Medan } \\ \text { (UNIMED) dalam memutus mata } & \text { me } \\ \text { rantai penyebaran COVID-19 } & \text { adalah } \\ \text { melaksanakan pembelajaran } & \text { dalam } \\ \text { jaringan (daring) pada } & \text { setiap }\end{array}$

matakuliah, jarak jauh secara online. Saat ini, UNIMED memberlakukan pembelajaran daring yang dilakukan dengan 2 cara, yaitu sinkronus dan asinkronus. Sinkronus (tatap maya) dilakukan dengan menggunakan media zoom, google meet, ataupun 
media virtual lainnya. Sementara, asinkronus dilakukan dengan menggunakan Learning Management System (LMS) Sistem Pembelajaran Daring (SIPDA) UNIMED. Dengan media ini, interaksi proses pembelajaran mahasiswa dengan dosen dapat terjalin dengan baik dan terprogram secara sistematis. Meskipun demikian, masih perlu dilakukan evalusi bersama baik dosen atau mahasiswa dalam memilih aplikasi dan memanfaatkannya sebagai sarana efektif dalam pembelajaran daring (Anim, 2020:72).

Layaknya sebagai alternatif kebijakan pembelajaran masa pandemi COVID-19, pembelajaran daring masih menimbulkan berbagai dinamika di lapangan. Bagi dosen misalnya, pembelajaran daring dirasakan efektif hanya yang bersifat penugasan, sementara ketercapaian tujuan perkuliahan yang berorientasi pada peningkatan pemahaman mahasiswa dinilai sulit dicapai. Bagi mahasiswa, permasalahan kemampuan teknologi dan faktor ekonomi yang kurang memadai turut juga menjadi kendala. Selain itu, koneksi internet yang kurang stabil, perangkat yang kurang memadai, dan keterbatasan kuota ikut serta menjadi penghambat dalam pembelajaran daring (Maulana \& Hamidi, 2020:225).

Meskipun demikian, kelebihan pembelajaran daring yaitu memudahkan antara maha siswa dengan dosen untuk tetap melaksanakan aktifitas perkuliahan
(Yunus, Setiawan, \& Wuryandini, 2020:1196).

Dinamika yang dikemukakan di atas dirasakan juga oleh mahasiswa PGSD FIP UNIMED khususnya pada matakuliah Kajian Kebahasaan semester genap 2020/2021. Faktor kemampuan teknologi dan ekonomi merupakan kendala utama dalam pembelajaran daring yang dilaksanakan. Mahasiswa yang tersebar di beberapa kabupaten/kota Sumatera Utara, Riau, Kepulaauan Riau, Nanggroe Aceh Darussalam, Sumatera Barat, dan Provinsi di sekitarnya jelas memiliki daya dukung jaringan/kesenjangan (digital gap) yang berbeda-beda. Kondisi ini ditambah dengan kemampuan ekonomi mahasiswa yang berbedabeda sehingga tidak mempunyai kemampuan dan kesanggupan yang sama dalam pembelajaran daring.

\section{METODE PENELITIAN}

Jenis penelitian yang dilakukan adalah penelitian deskriptif kualitatif. Populasi pada penelitian ini adalah seluruh mahasiswa semester II Prodi PGSD FIP UNIMED Tahun Ajaran 2020/2021. Sampel penelitian berjumlah 187 responden yang diambil dengan menggunakan teknik purposive sampling terfokus pada mahasiswa yang terlibat aktif mengisi instrumen penelitian. Instrumen penelitian menggunakan kuesioner yang diisi mahasiswa secara daring dalam bentuk Google Form. Teknik analisis data yang digunakan adalah analisis kualitatif dengan tahapan pengumpulan data, reduksi data, 
Faisal : Potret Pembelajaran Daring Matakuliah ...

penyajian data, dan penarikan simpulan.

HASIL PENELITIAN DAN PEMBAHASAN

\section{Proses Belajar Mengajar}

Ada 5 aspek yang dibahas berkaitan dengan proses belajar mengajar pada matakuliah Kajian Kebahasaan, antara lain: (a) pelaksanaan perkuliahan dapat diakses dengan mudah, (b) pelaksanaan perkuliahan dilaksanakan tepat waktu dan sesuai dengan jadwal, (c) perkuliahan secara daring menambah pemahaman teori dan keterampilan, dan (d) materi yang disajikan secara daring sesuai dengan kontrak perkuliahan/RPS, dan (5) kemudahan dalam mengirimkan tugas/berita acara perkuliahan. Untuk lebih jelasnya dideskripsikan sebagai berikut.

Tabel 1. Jawaban Responden Aspek Proses Belajar Mengajar

\begin{tabular}{|c|c|c|c|c|c|c|c|c|}
\hline \multirow{2}{*}{ No. } & \multirow{2}{*}{ Aspek } & \multicolumn{5}{|c|}{ Skor $(\%)$} & \multirow{2}{*}{$\begin{array}{c}\text { Skor } \\
\text { Rata-rata }\end{array}$} & \multirow{2}{*}{ Kategori } \\
\hline & & 5 & 4 & 3 & 2 & $\overline{1}$ & & \\
\hline 1. & Pelaksanaan perkuliahan dapat diakses dengan mudah & 34.8 & 41.2 & 21.4 & 1.6 & 1.1 & 4.07 & Baik \\
\hline 2. & $\begin{array}{l}\text { Pelaksanaan perkuliahan dilaksanakan tepat waktu dan } \\
\text { sesuai dengan jadwal }\end{array}$ & 34.8 & 39.6 & 21.9 & 3.2 & 0.5 & 4.05 & Sering \\
\hline 3. & $\begin{array}{l}\text { Perkuliahan secara daring menambah pemahaman teori } \\
\text { dan keterampilan }\end{array}$ & 20.3 & 36.9 & 34.2 & 4.4 & 2.1 & 3.67 & Baik \\
\hline 4. & $\begin{array}{l}\text { Materi yang disajikan secara daring sesuai dengan } \\
\text { kontrak perkuliahan/RPS }\end{array}$ & 60.4 & 30.5 & 6.4 & 1.6 & 1.1 & 4.48 & Sering \\
\hline 5. & $\begin{array}{l}\text { Kemudahan mahasiswa dalam mengirimkan tugas/berita } \\
\text { acara perkuliahan }\end{array}$ & 50.8 & 33.7 & $12 . .3$ & 2.7 & 0.5 & 4.31 & Sering \\
\hline
\end{tabular}

Berdasarkan Tabel 1, dapat dilihat bahwa respon mahasiswa terhadap pelaksanaan perkuliahan dapat diakses dengan mudah dengan kategori Sangat Baik ada 34,8\%, kategori Baik ada 41,2\%, kategori Cukup ada 21,4\%, kategori Tidak Baik ada 1,6\%, dan kategori Sangat Tidak Baik ada $1,1 \%$. Secara umum, rata-rata responden mahasiswa berada pada 4,07 dengan kategori Baik.

Respon mahasiswa kategori Selalu ada $34,8 \%$, kategori Sering ada $39,6 \%$, kategori Kadang-kadang ada $21,9 \%$, kategori Jarang ada 3,2\%, dan kategori Tidak Pernah ada 0,5\%. Secara umum, rata-rata respon mahasiswa berada pada skor 4,05 dengan kategori Sering. Hasil respon mahasiswa Baik ada 6,4\%, dan kategori Sangat Tidak Baik 2,1\%.
Rata-rata respon mahasiswa berada pada skor 3,67 dengan kategori Baik.

Kemudahan mahasiswa dalam mengirimkan tugas/berita acara perkuliahan dengan kategori Selalu ada 50,8\%, kategori Sering ada $33,7 \%$, kategori Kadang-kadang ada 12,3\%, kategori Jarang 2,7\%, dan kategori Tidak Pernah ada 0,5\%. Rata-rata respon mahasiswa terhadap kemudahan dalam mengirimkan tugas/BAP berada pada skor 4,31 dengan kategori Sering.

Berdasarkan data respon mahasiswa keseluruhan diperoleh simpulan bahwa kegiatan proses belajar mengajar pada matakuliah Kajian Kebahasan di Prodi PGSD FIP UNIMED tergolong Baik dengan skor rata-rata 4,11 . 
Kapabilitas/Kompetensi Dosen

Kapabilitas/kompetensi dosen

dalam pembelajaran daring dianalisis berdasarkan 6 aspek Untuk lebih jelasnya dapat dilihat pada Tabel 2 berikut.

Tabel 2. Jawaban Responden Aspek Kapabilitas/Kompetensi Dosen

\begin{tabular}{|c|c|c|c|c|c|c|c|c|}
\hline \multirow{2}{*}{ No. } & \multirow{2}{*}{ Aspek } & \multicolumn{5}{|c|}{ Skor (\%) } & \multirow{2}{*}{$\begin{array}{c}\text { Skor } \\
\text { Rata-rata }\end{array}$} & \multirow{2}{*}{ Kategori } \\
\hline & & 5 & 4 & 3 & 2 & 1 & & \\
\hline 1. & $\begin{array}{l}\text { Dosen selalu menemani ketika pembelajaran secara daring } \\
\text { hingga selesai }\end{array}$ & 50.8 & 31.6 & 10.2 & 4.8 & 2.7 & 4.23 & Sering \\
\hline 2. & $\begin{array}{l}\text { Dosen menjelaskan arah dan tujuan dalam setiap } \\
\text { pembelajaran secara daring }\end{array}$ & 50.8 & 36.4 & 7.5 & 2.1 & 3.2 & 4.29 & Sering \\
\hline 3. & $\begin{array}{l}\text { Dosen memberikan kesempatan mahasiswa untuk bertanya } \\
\text { dan berdiskusi }\end{array}$ & 76.5 & 18.2 & 2.1 & 0.5 & 2.7 & 4.65 & Selalu \\
\hline 4. & $\begin{array}{l}\text { Dosen memberikan respon terhadap pertanyaan yang } \\
\text { muncul selama perkuliahan secara daring }\end{array}$ & 56.1 & 33.2 & 4.3 & 2.1 & 4.3 & 4.35 & Sering \\
\hline 5. & $\begin{array}{l}\text { Tingkat pemahaman mahasiswa secara umum terhadap } \\
\text { mata kuliah yang disajikan dosen secara daring }\end{array}$ & 17.1 & 58.8 & 18.7 & 3.7 & 1.6 & 3.86 & Baik \\
\hline 6. & $\begin{array}{l}\text { Dosen memantau keaktifan dan attitude/sikap mahasiswa } \\
\text { selama perkuliahan }\end{array}$ & 49.2 & 36.4 & 9.6 & 2.7 & 2.1 & 4.28 & Sering \\
\hline
\end{tabular}

Berdasarkan data pada Tabel 2, dapat dijelaskan bahwa respon mahasiswa berkaitan dengan kategori Selalu ada 50,8\%, kategori Sering ada $31,6 \%$, kategori Kadang-kadang ada $10,2 \%$, kategori Jarang ada 4,8\%, dan kategori Tidak Pernah ada 2,7\%. Rata-rata skor responden berada pada skor 4,23 pada kategori Sering.

Respon mahasiswa berkaitan dengan kategori Selalu ada 50,8\%, kategori Sering ada 36,4\%, kategori Kadang-kadang ada 7,5\%, kategori Jarang ada $2,1 \%$, dan kategori Tidak Pernah ada 3,2\%. Rata-rata skor responden berada pada skor 4,29 pada kategori Sering.

Respon mahasiswa berkaitan dengan dosen memberikan respon terhadap pertanyaan yang muncul selama perkuliahan secara daring dengan kategori Selalu ada 56,1\%, kategori Sering ada 33,2\%, kategori Kadang-kadang ada 4,3\%, kategori Jarang ada 2,1\%, dan kategori Tidak Pernah ada 4,3\%. Rata-rata skor responden berada pada skor 4,35 pada kategori Sering.

Respon mahasiswa berkaitan dengan kategori Sangat Baik ada 17,1\%, kategori Baik ada 58,8\%, kategori Cukup ada 18,7\%, kategori Tidak Baik ada 3,7\%, dan kategori Sangat Tidak Baik ada 1,6\%. Ratarata respon mahasiswa berada pada skor 3,86 dengan kategori Baik.

\section{Pembahasan}

\section{Sarana dan Prasarana}

Aspek ketersediaan materi kuliah dalam pembelajaran daring, baik di internet, media online, artikel, atau buku elektronik dapat dilihat pada Gambar 1 berikut.
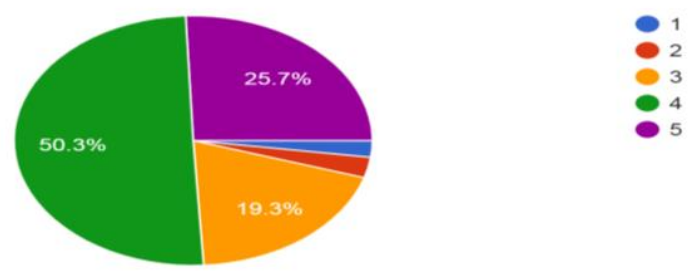

Gambar 1. Ketersediaan Materi Kuliah dalam Pembelajaran Daring 
Berdasarkan Gambar 1, dapat dijelaskan bahwa respon mahasiswa yang menyatakan bahwa ketersediaan materi kuliah dalam pembelajaran daring dengan kategori Sangat Baik ada $25,7 \%$, kategori Baik ada 50,3\%, kategori Cukup ada 19,3\%, kategori Tidak Baik ada 2,7\%, dan kategori Sangat Tidak Baik ada 2,1\%. Rata- rata skor respon mahasiswa berada pada 3,94 dengan kategori Baik.

Respon mahasiswa berkaitan dengan memiliki sarana dan prasarana pendukung dalam pembelajaran daring misalnya handphone atau laptop serta jaringan memadai dapat dilihat pada Gambar 2 berikut.
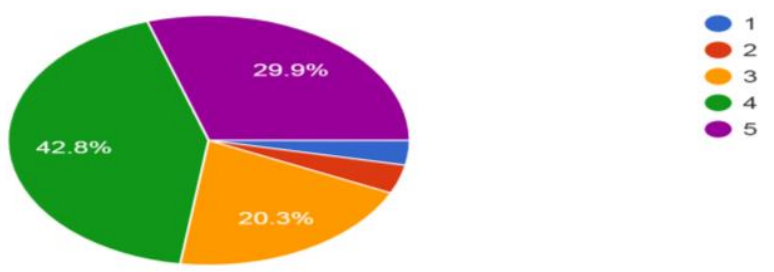

\section{Gambar 2. Mahasiswa Memiliki Sarana dan Prasarana Memadai}

Merujuk pada Gambar 2, dalam pembelajaran daring dengan dapat dijelaskan bahwa respon skor rata-rata 3,93. Namun demikian, mahasiswa terkait dengan memiliki sarana dan prasarana pendukung dalam pembelajaran daring misalnya handphone atau laptop serta jaringan memadai dengan kategori Sangat Baik ada 29,9\%, kategori Baik ada $42,8 \%$, kategori Cukup ada 20,3\%, kategori Tidak Baik ada 3,7\%, dan kategori Sangat Tidak Baik ada 3,2\%. Rata-rata respon mahasiswa berada pada skor 3,92 dengan kategori Baik.

Berdasarkan data pada kedua aspek yang dianalisis, disimpulkan bahwa mahasiswa mempunyai sarana dan prasarana pendukung yang baik yang menjadi catatan adalah masih terdapat $27,2 \%$ mahasiswa yang perlu mendapat perhatian dari dosen berkaitan dengan ketersediaan sarana dan prasarana pendukung dalam pembelajaran daring misalnya handphone atau laptop serta jaringan memadai.

\section{Tantangan dan Kendala}

Tantangan dan kendala yang dialami mahasiswa dalam pembelajaran daring dapat dilihat secara jelas pada Gambar 3 dan 4 berikut.
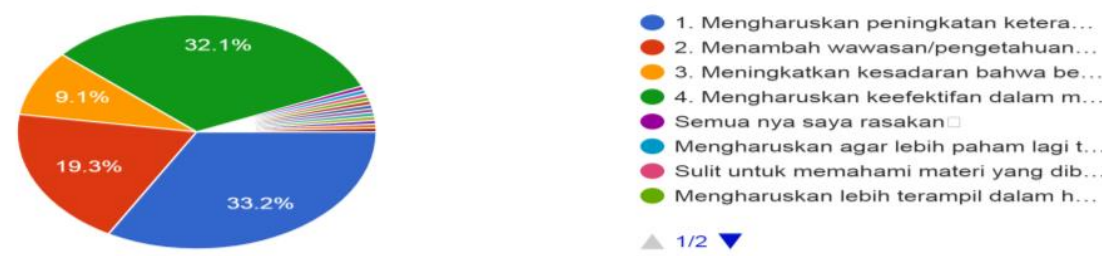

Gambar 3. Tantangan Mahasiswa dalam Pembelajaran Daring 
Berdasarkan data pada (32,1\%) (3) menambah Gambar 3, dapat dilihat bahwa wawasan/pengetahuan tentang tantangan mahasiswa dalam pembelajaran daring (19,3\%), (4) pembelajaran daring diurutkan meningkatkan kesadaran bahwa sebagai berikut: (1) mengharuskan belajar daring bermanfaat untuk diri peningkatan keterampilan IT $(33,2 \%), \quad$ sendiri $(9,1 \%)$, dan lainnya $(6,3 \%)$.

(2) mengharuskan keefektifan dalam manajemen waktu
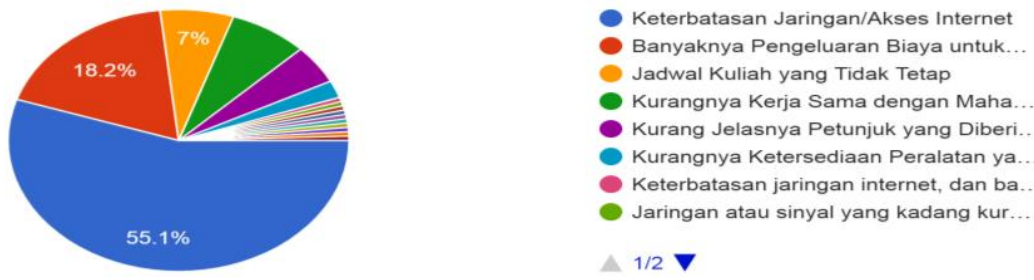

\section{Gambar 4. Kendala Mahasiswa dalam Pembelajaran Daring}

Kendala yang dihadapi mahasiswa selama pembelajaran daring dideskripsikan sebagai berikut: (1) keterbatasan jaringan/akses internet $(55,1 \%), \quad(2)$ banyaknya pengeluaran biaya untuk paket internet dan bahan kuliah (18,2\%), (3) kurangnya kerjasama dengan mahasiswa lain $(7,5 \%)$, (4) jadwal kuliah yang tidak tetap (7\%), (5) kurang jelasnya petunjuk yang diberikan dosen $(4,8 \%)$, dan lainnya $(7,4 \%)$.

\section{SIMPULAN}

Merujuk pada data respon mahasiswa keseluruhan diperoleh simpulan temuan penelitian sebagai berikut: (1) kegiatan proses belajar mengajar pada matakuliah Kajian Kebahasan di Prodi PGSD FIP UNIMED tergolong Baik dengan skor rata-rata 4,11 ,

kapabilitas/kompetensi dosen dalam mengajar secara daring menunjukkan respon yang baik/positif dari mahasiswa dengan skor rata-rata 4,28 dengan kategori Baik, (3) mahasiswa mempunyai sarana dan prasarana pendukung yang baik dalam pembelajaran daring dengan skor rata-rata 3,93, dan (4) tantangan ini mengharuskan peningkatan keterampilan IT dan keefektifan dalam manajemen waktu. Sementara, kendala yang ada di lapanagn seperti keterbatasan jaringan/akses internet dan banyaknya pengeluaran biaya untuk paket internet dan bahan kuliah.

\section{DAFTAR RUJUKAN}

Abi Yodha, S., Abidin, Z., \& Adi, E. P. 2019. Persepsi Mahasiswa Terhadap Pelaksanaan ELearning Dalam Mata Kuliah Manajemen Sistem Informasi Mahasiswa Jurusan Teknologi Pendidikan Universitas Negeri Malang. Jurnal

Kajian 
Faisal : Potret Pembelajaran Daring Matakuliah ...

Teknologi Pendidikan, 2(3), 181-187.

Anim, A. 2020. Persepsi Mahasiswa Pendidikan Matematika tentang Pembelajaran Daring Selama Masa Learn from Home (LFH) Pandemic Covid-19. JURNAL

MATHEMATIC

PAEDAGOGIC, 5(1), 72-80.

Maulah, S., \& Ummah, N. R. 2020.

Persepsi Mahasiswa Biologi terhadap Perkuliahan Daring Sebagai Sarana Pembelajaran Selama Pandemi Covid 19. ALVEOLI: Jurnal Pendidikan Biologi, 1(2), 4961.

Maulana, H. A. 2021. Persepsi Mahasiswa terhadap Pembelajaran Daring di Pendidikan Tinggi Vokasi: Studi Perbandingan antara Penggunaan Google Classroom dan Zoom Meeting. Edukatif: Jurnal Ilmu Pendidikan,3(1), 188195.

Maulana, H. A., \& Hamidi, M. 2020. Persepsi Mahasiswa terhadap Pembelajaran Daring pada Mata Kuliah Praktik di Pendidikan

Vokasi. Equilibrium: Jurnal Pendidikan, 8(2), 224-231.

Ningsih, S. 2020. Persepsi Mahasiswa terhadap Pembelajaran Daring pada Masa Pandemi Covid19. JINOTEP (Jurnal Inovasi dan Teknologi Pembelajaran): Kajian dan Riset dalam
Teknologi Pembelajaran, 7(2), 124-132.

Yunus, M., Setiawan, D. F., \& Wuryandini, E. 2021. Persepsi Mahasiswa terhadap Pembelajaran Online pada masa Pandemi COVID19. Jesya (Jurnal Ekonomi dan Ekonomi Syariah), 4(2), 1196-1202. 